DOI https://doi.org/10.36059/978-966-397-117-9/36-55

\title{
FEATURES OF THE IMPLEMENTATION OF THE REFORM OF PUBLIC ADMINISTRATION AND THE PROVISION OF ADMINISTRATIVE SERVICES IN UKRAINE
}

\author{
Bortnyak K. V.
}

\section{INTRODUCTION}

According to the theory of organizations, a comprehensive development of the country is possible only with the targeted effective functioning of all its elements. Territorial and administrative components of any state are grassroots structural units that form its administrative and territorial division. Necessity of administrative reform came up simultaneously with the independence of Ukraine. Absence of political will, changes in political system and periodic elections and crisis hold over this process. Main problem on the way of building effective administrative and system of giving public service is the division of power between local government and central administration. Division of power, financial resources and control are three whales, that made base for an effective model of local self-government. Key-problems of implementation administrative reform in Ukraine are: 1) the principle of «voluntary» community association, 2) it is impossible to reform the local government without changes to the Constitution, 3) local elections take place on the old territorial basis, 4) conservatism of the local elite and the reluctance to change anything at all. Moreover the key-myth is that the administrative-territorial structure of the country will be radically changed, and in fact the map of Ukraine will be re-mapped. The reality is that the major changes will affect the local level - the community, the number and boundaries of regions and districts will not be changed. The practical implementation of the administrative reform involves changes in three dimensions: 1) territorial (change of administrative-territorial system), 2) administrative (delegation of significant powers to the local level, change of power vertical), 3) financial (redistribution of budget funds in order to target them to community level). To summarize, the political consensus on the model of the territorial structure of Ukraine and on the status of the Donbas is necessary for the successful implementation of the administrative reform. Administrative reform should be aimed 
primarily at satisfying the needs of the community in order to improve their standard of living and provide quality management services.

\section{Principles of the establishment of administrative reform in Ukraine}

The reformation of regional policy in Ukraine has started with decentralization of public administration and reformation of local government based on experience of the EU members and in particularly, Poland. In Ukraine the decentralization is first mentioned in the Constitution of Ukrainian People's Republic on April 29, 1918, which states: without breaking unitarily power UNR provides its lands and communities rights for wide self-government according to the principle of decentralization. The excessive centralization of regional development, which has been a norm for Ukrainian regional policy till 2013, has resulted in many negative consequences. It has contributed to the increase of contradictions between «center» and regions, and between «communities-districts-regions», that impeded regional social and economic development, and led to the emergence of destructive ideas of federalization. The process of reformation of public administration in Ukraine should be comprehensive and consistent.

The priority aspects of decentralization should include: the shift away from centralized model of regional development; the economic viability of regions and local self-government; the building of the effective system of territorial organization of power. The decentralization of state government as a base for reformation of Ukrainian regional policy involves: i) the transfer of powers, responsibilities and resources from national level to local governments and regional authorities; ii) the increase of the power of local communities in their relations with the center; iii) granting regions the right to develop and implement their own development strategies; iv) the concentration of resources required for internal development. Under decentralization the great importance must be given to the issues of financial security of regions based on the securing of stable sources of tax revenue, and the differentiated provision of educational and medical subventions.

The implementation of such trends will contribute to social and economic development of regions and communities, create opportunities to provide high-quality services to all citizens, strength the principle of democracy in work, and ensure the formation and implementation of their own strategies for social and economic development without excessive administrative control of national government. Ukraine anticipates the 
fiscal decentralization, the strengthening of the fiscal autonomy of local governments on the basis of revenue sharing between the center, local authorities and local governments, which requires changes in the existing system of the interaction of budget levels (that is, the list of fixed incomes and standard withholdings from regulated revenues at all levels for a long term, not less than 5 years).

The decentralization of the budget process stipulates the increasing number of financial sources for local budgets, in particular by the attaching for local budgets some part of the corporate income tax of the companies operating within the respective territories, excise duty, environmental tax, subsoil use fees, the fees for special use of national natural resources etc. The state budget should be formed in the amount needed to finance the government, the defense and security, important national programs and funds of convergence of social and economic development of regions. The state should thus make the budgetary provision for residents in all administrative units at the guaranteed level established by law. Essence and importance of administrative and territorial reform Ukraine has so far retained the two-level territorial divisions that emerged in former USSR ${ }^{1}$.

First level is region (oblast), second is districts and all settlements (cities of regional subordination, urban settlements, and villages). As of 1 January 2014 the territorial and administrative system included: the Autonomous Republic of Crimea, 24 regions, cities of Kyiv and Sevastopol, 490 districts, 460 cities, 885 towns, 10279 village councils, 28397 villages $^{2}$.

The current territorial structure of Ukraine is characterized by: the existence of disparities in regional development; the different availability of services including administrative ones; the uneven funding of territorial and administrative units calculated as per capita; the complex mechanism of interaction between local authorities and locals; the imperfect system of local self-government. The inefficiency, inconsistency, excessive centralization, distance from the interests of real people are typical for the current territorial and administrative system. The existing territorial and administrative structure does not promote the effective regional development. It causes problems of social and economic recession and the depopulation of much of the country. Under current conditions a comprehensive territorial and administrative reform has become

\footnotetext{
${ }^{1}$ The Constitution of Ukraine: Official text - Kyiv : Palyvoda A. V. 2016. 64 p.

${ }^{2}$ Derzhavna sluzhba statystyky Ukrayiny [Elektron. resurs]. http://www.ukrstat.gov.ua/.
} 
particularly important and necessary taking into consideration an aggravation of political and economic situation and European line of development in Ukraine.

The territorial and administrative reform should provide for the changes in the territorial and administrative structure and organizational system, and the national and local authority performance. The government work should be aimed at creating more supportive environment for social development based on the balance of individual, collective (public) and national interests. The goal of reform is to strengthen territorial unity of the country and to ensure more effective regulation of society development, allocation of economic and financial resources, expansion of facilities and financial framework of territorial and administrative units. The decentralization of power will reduce social and political tensions in the country, and promote its comprehensive development.

The necessity for administrative and territorial reform is caused by obsolescence and mismatch of the current structure to the modern development of Ukrainian economy and to the system of its functioning mechanism that has negative impact on political and economic system of the country. The current territorial structure of Ukraine is characterized by the excessive dissemination of administrative units on local level. Most of them do not have sufficient economic potential for development. The main tasks of territorial and administrative reform in Ukraine should be following: the decentralization of public authority, the enhancing role of local selfgovernment and its reformation through consolidation of territorial units in accordance with the NUTS system.

In the process of territorial and administrative reform it is necessary to ensure: the transition to new system of territorial and administrative structure based on formation of integral territorial and administrative units; their administrative, financial, economic, social, demographic security with respect to the regional features. It is also necessary to define the nature and limits of national government control over the local governments; to develop the organizational and economic mechanism for the strengthening of economic base and the providing of financial and managerial autonomy of administrative units.

The reform of territorial and administrative structure and spatial organization of power in Ukraine is one of the fundamental reforms, which affect almost all spheres of society. Thus its successful accomplishment requires broad public support. This, in turn, requires the frank and broad media exposure of reform process and problems. The 
efforts of regional authorities at all levels should be aimed at the promoting of convergence. For this purpose it is necessary to develop the science-based innovation strategy for the restructuring of regional economy; to provide the broader support for development of business environment; to promote the consulting, education, research and technological development; to provide for the concessional loans to industrial enterprises and organizations conducting research and development; to involve the government orders mainly in the form of contracts for R\&D and production of new innovative products; to promote the development of international leasing, joint venture, venture capital; to ensure priority allocation of investment, financial and credit resources for creation of new jobs in information-intensive industry sectors; to use more efficiently the existing scientific potential by means of reducing gaps of interdisciplinary connections in cycle «fundamental researchdevelopment- commercialization of knowledge in production»; to create the national database to monitor the development of research and innovation process in every region of Ukraine.

Currently, there are no adopted framework regulations concerning new model of territorial and administrative structure of Ukraine. It is necessary to adopt law «On territorial and administrative structure», which will define stages of reform, objectives and criteria of evaluation at every stage; specific provisions and clear requirements for the formation of territorial and administrative units on each level. It has to suggest the optimal model, which will combine power of central government, on the one hand, and on the other, will contribute to the development of democratic governance by strengthening the role of local self-government. Model of territorial and administrative reform At different stages of historical development the territorial and administrative system of Ukraine has undergone significant changes.

In early 20th century country was divided between Russian and Austro-Hungarian Empire. In Russian Empire Ukrainian ethnic territory consisted of 9 governorates divided into 90 counties. As part of the Austro-Hungarian Empire there were such Ukrainian lands as Galicia, Bukovina, and Transcarpathian Ruthenia with corresponding division into counties. After the collapse of both empires in the beginning of 20th century Soviet Ukraine was divided into circuits and districts, and later division was changed to regions (oblasts) and districts. In 1962 there was an attempt to unite oblasts into seven economic zones (councils of 
national economy) - Donetsk, Kyiv, Lviv, Dnipro, Kharkiv, Black sea, but later they switched to the division into regions (oblasts) and districts.

This division has remained until now. The new model of territorial and administrative division should be based on the spatial paradigm providing for the metropolitan spatial economic systems drawing on the existing settlement systems, which have been transforming under the influence of processes of economic zoning and metropolisation. The economic zoning should rest on the consideration of historical, natural, ecological, social and economic characteristics of Ukrainian territory.

European integration processes taking place in Ukraine afford ground for the conducting of territorial and administrative reform in accordance with the EU common system of classification of territorial and administrative units for statistics - NUTS (Nomenclature of Territorial Units for Statistics: NUTS I (3 million of people -7 million of people), NUTS II (800 thousand of people -3 million of people), NUTS III (159 thousand of people -800 thousand of people).

The implementation of NUTS in Ukraine may be considered as one of most important steps towards enabling Ukraine's joining the single European Statistical System, that will provide a unified, transparent and effective monitoring and as a result the implementation of effective regional policy. I argue that the reformation of existing Ukrainian territorial structure envisages the creation of first-degree units - NUTS III communities (a group of villages, settlements, towns); NUTS II counties that will cover several modern administrative districts. The third level will be presented by economic areas that be created by combining existing regions in accordance with the level of NUTS 1. Taking into account experience of CEE countries, where under European integration the territorial and administrative reform took place gradually in two stages, the territorial and administrative reform in Ukraine should be also conducted in two stages.

At first present stage, it is important to guarantee the reformation of basic level NUTS III, which should be formed by combining local communities (with a population of at least 5-6 thousand people in accordance with the recommendations of the World Bank). The formation of territorial communities should be based on existing regional settlement systems through the merger around a certain core (centers of economic development) of village, town and city councils in accordance with economic, social, demographic, historical, infrastructural, administrative and managerial, natural and geographical, mental features of their 
territories, as well as the principle of territorial access to social, administrative and public services and proper economic fundamentals: property, appropriate property rights, natural and other resources, assets of local budgets, which should be sufficient for resolving local issues within their competence ${ }^{3}$.

The greatest distance of settlements from the center of the community is determined, as a rule, by basic requirements of social services at this level, especially by timing: emergency aid (15-20 $\mathrm{min}$ ), delivery of secondary school students by school bus (15-20 min), emergency rescue $(15 \mathrm{~min})$. Regional public authorities have to develop systems of local communities. At the end of 2015, most regions of Ukraine approved long-term plans of territorial communities reforming, but their implementation requires a proper institutional and methodical support. Still the regulatory acts about system of organization and legal, financial and economic mechanisms aimed at the establishment and development of territorial communities has not been adopted. Ukrainian experts have offered some methods ${ }^{4}$.

For example, in Lviv region the Perspective plan of creation of 140 capable territorial communities was developed. For the stimulation of social and economic development it is expected to provide people with state financial support in the amount of three million hryvnias, and in addition, to transfer to the communities over 190 thousand hectares of land beyond their territories. Existing district level in Ukraine (150800 thousand of people) does not meet the level of NUTS II (from 800 thousand to 3 million of people). It is necessary to unite areas on the basis of existing settlement systems and interrelationships, and to form appropriate territorial units of the second level - that is districts (powiets) with the corresponding amount of population.

Moreover, because of existing interdistrict connections in some regions the system may cover the administrative regions of adjacent regions that should be considered during the formation of NUTS I. Districts should deal with the matters that the community cannot solve themselves: protection of public order, disaster management, flood and fire control, maintenance of general hospitals, social assistance, unemployment, and construction of roads. Thus, as a result of the first

\footnotetext{
Zakon Ukrayiny «Pro dobrovil'ne ob’yednannya terytorial'nykh hromad» [Elektronnyy resurs]. http://zakon4.rada.gov.ua

Proekt metodyky formuvannya spromozhnykh terytorial'nykh hromad [Elektronnyy resurs]. http://www.minregion.gov.ua.
} 
stage of reform, territorial and administrative division of Ukraine will consist of communities (NUTS III) and district (NUTS II). As an example I single out with help of gravitational model five districts in Lviv region Lviv, Drogobych, Zolochiv, Brody, Chervonohrad - and five districts in Ternopil region - Ternopil, Chortkiv, Kremenets, Berezhany, Shuya. I agree with V. Kolosov that the current population of the highest level of territorial and administrative division of Ukraine - region (oblast) corresponds by quantitative parameters to NUTS II level ${ }^{5}$.

In this regard, at the second stage of territorial and administrative reform it is necessary to start formation of NUTS I by combining economic areas with regard to agglomeration-metropolitan method. The centers of selected economic areas should become large cities with million or more people, on basis of which metropolitan spatial economic systems would be formed. Those systems are the foundation of national economy, sources of new ideas, technologies and innovations, generators, stimulants of economic growth. The economic zoning involves the division of national economy into relatively independent systems, each of which differs by appropriate level of public, economic, social integrity and independence. The economic areas may be considered as the concentration of historical, economic, political and social processes in a specific cultural environment, as part of the spatial structure of society.

The economic areas might become businesses-structures which «are able to adapt to the global economy and produce wealth», in other words, it should be optimal space to get the best social and economic results. Studying of national economic space zoning involves two interrelated approaches: qualitative (system) and quantitative (cybernetic). The goal of economic zoning should be the realization of strategy of increasing competitiveness of national economy based on sustainable long-term spatial social and economic development. The maintenance of regional transport infrastructure, specialized health care and specialized secondary education, development of culture, sports, tourism, providing a higher level of service (higher education, health care, cultural institutions) is proposed to transfer to NUTS I level.

The economic area level should also include the development and implementation of social and economic development policy and resolving of issues of inter-regional and national importance: the creating of conditions for economic development; the balancing of labor market; the

\footnotetext{
5 Kolosov V. Territorial units in Russia,Ukraine, Belarus and Moldova and NUTS classification. V. Kolosov. [Elektronnyy resurs]. http://www.ums-riate.fr/Webriate/wp-content/uploads/2015/03/M4D.pdf.
} 
implementation of projects to support small and medium-sized enterprises; advertising; the initiation of appropriate organizational forms to attract investment and international financial assistance (agencies, foundations of regional development); the organization of inter-regional cooperation, development and implementation of strategies and programs for regional development; the maintenance and development of regional social and technical infrastructure to support the science education, and culture (theaters, philharmonic, museums); the sustainable use of natural resources and preservation of the environment; the maintenance of emergency medical care facilities, specialized medical care and rehabilitation, diagnosis, as well as specialized schools. During first years of independence (1990-1996) Ukrainian scientists have proposed various options for integrated economic zoning. Authors proposed to single out from ten to six economic regions in Ukraine. The main principles of their allocation were: social and historical features; commensurable levels of industrial development, scientific and technological and cultural potentials.

\section{The system of providing new administrative services in Ukraine}

The priority in the sphere of provision of administrative procedures and adminis-trative services is adoption of the law on the general administrative procedure in accordance with the European standards, and gradual harmonization of individual administrative services with the identified general principles. Implementation of the general administrative procedure should be based on the principles of legality, a right to effective protection, provision of a decision clearly stating the grounds for adoption thereof, a right to non-judicial appeal, a right to appeal in court, etc. To ensure implementation of a decision of the Coordination Council on Public Administration, the Ministry of Justice created a working group on drafting a law on administrative procedure for defining the basic principles and rules of adminis-trative procedure.

This will facilitate legal clarity and provision of guarantees of respect for the rights of citizens and legal entities in cases when state agencies determine their rights and responsibili-ties. It is planned to prepare and adopt the draft law On Administrative Procedure in the current year. For improving the quality of provision of administrative services for citizens and economic actors in accordance with the European requirements, decreasing corruption risks during provisions of administrative services, 
and increasing investment attractiveness and competi-tiveness of the country, the Cabinet of Ministers approved the action plan for implementation of the Concept on devel-opment of the system of provision of e-services. The administrator of the unified state portal of administrative services is the State Research and Development Institute of Informatization and Economic Modeling falling under the sphere of management of the Ministry of Economic Development ${ }^{6}$.

The Institute will be responsible for tech-nical administration, development and proper functioning, integration of state authorities and local self-government bodies into the Portal of information systems.For 2018 , it is planned integrate the systems of electronic interaction of executive bodies with the Portal and to build a comprehensive system for protection of respective information. Completion of these activities will significantly increase the number of administrative services provided in an electronic form according to the one-stop-shop principle, and it will decrease the time necessary for submission of documents required for receiving an administrative service, and it will furthermore ensure protection of information on the Portal in accordance with the legislation.

The quality and accessibility of adminis-trative services was growing also due to the centers for provision of administrative services and decentralization of basic administrative services. Special attention was paid to further development of the centers for provision of administrative services, and to increasing the number of administrative services provided by such centers as well as increasing the quality of provision thereof.

In 2017, 64 new CPAS were opened - from 682 in 2016 to 746 as of the end of 2017. In the united territorial communities, 71 CPAS are already functioning, and in 2017 their number increased by 50.A list of services provided by the CPAS increased - on average, from 84 in 2016 to 95 services in 2017. Pursuant to the CMU executive order a list of CEB services to be provided by CPAS was increased to 136.In 2017, CPAS provided 11 million services, which is $33 \%$ more than in 2016 (8.3 million services). On average, every day all Centers provide more than 40000 services to individuals and legal entities. The existing network of the Centers was analyzed, the results of which identified 240 "blank spaces", and network optimi-zation was suggested. The plan forensuring 30-minute accessibility was suggested.Standards of quality of provision of

\footnotetext{
${ }^{6}$ Transformation of international economic relations: modern challenges, risks, opportunities and prospects: collective monograph. edited by M. Bezpartochnyi, in 3 Vol. ISMA University. Riga: «Landmark» SIA, 2017. Vol. 3. P. 101
} 
servic-es to CPAS visitors were developed, and CPAS administrators were informed about them during 14 specialized training sessions. To ensure implementation of these standards in practice, a respective online course was developed, which is available on the Open University of Maidan (VUM)* platform. As of January 9, 2018 the course was completed by 821 persons, and as of March 12, 2018 - by 1683 persons $^{7}$.

In order to improve the CPAS work, the system for evaluation of performance of centers for provision of administrative services was introduced, which is used for ongoing monitoring of their activities, and the results are posted on the official web-site of the Ministry of Economic Development on a quarterly basis. Based on the analysis of monitoring results, proposals are forwarded to the Cabinet of Ministers and to central executive bodies. Among other things, these proposals may refer to improving performance of the centers for provision of administrative services (forwarded to oblast state admin-istrations and local selfgovernment bodies), and issues pertaining to ensuring interaction of CEBs with the canters for provision of administrative services. Proposals were submitted for respective draft normative legal acts. Seminars and round tables were conduct-ed with participation of CPAS staff and the public for discussing the quality of services and searching the ways to improve them.

The Law of Ukraine on Fiduciary Services was approved, and a draft normative legal act was prepared on identifying the mechanism of electronic identification of citizens for receiving administrative services in an electronic form, including through the mobile ID.

In order to decrease the administrative pressure and to optimize the procedure for provision of electronic administrative services, the Government identified 15 most popular services (re-engineering), and prepared a plan for theiroptimization.

Analytical study was conducted to explore the situation, problems and prospects of developing 23 highest priority state elec-tronic information resources for imple-menting electronic interaction, and a roadmap was prepared for developing national interoperability.Procurements were organized and a respective contract was signed for the System of Electronic Interaction of State Electronic

\footnotetext{
${ }^{7}$ Report On The Investigation Into Russian Interference In The 2016 Presidential Election. Volume I of II. Special Counsel Robert S. Mueller, III. Submitted Pursuant to 28 C.F.R. § 600.8(c). Washington, D.C. March 2019. [Elektronnyy resurs]. https://www.nytimes.com/interactive/2019/04/18/us/ politics/mueller-reportdocument.html.
} 
Information Resources (herein-after - SEI SEIR) Trembita. The system is development within the framework of the the EGOV4UKRAINE project that provided support to the program of decentraliza-tion in Ukraine EGOV4UKRAINE with financing from the European Union, and with support of cooperation development framework of Sweden and Estonia.

As of today, the feature set for the soft-ware maintaining the SEI SEIR infrastruc-ture was developed and tested, industrial, test, and training environment of the SEI SEIR was installed on the servers of the State Agency for E-Governance, and work was started to connect the basic state registers to the SEI SEIR. In 2017, it 28700000 hryvnias were allocated from the State Budget for financing development, administration and maintenance offunctioning of the system of electronicinteraction of the state electronicinformation resources.

The Government created a uniform state open data web-portal, data.gov.ua. The portal provides access to public informa-tion in the form of open data and envisag-es access to information for state authori-ties for its further use. During the period of existence, more than 27480 data sets were posted on the unified state open data portal, and more than 2000 manag-ers of such sets were registered. In 2016, more than 11000 open data sets were registered, and more than 800 managers of information were registered; in 2017, more than 16000 open data sets were registered, and more than 1200 new managers of information were registered ${ }^{8}$.

On December 20, 2017 the Cabinet of Ministers adopted a resolution on amend-ing the Provisions on data sets subject to publication in the form of open data (79). This document will make it possible to increase the number of data sets for publication from 300 to 616 .

Conducted activities include:

two assessments of the status of publication and update of the data sets in the uniform state open data porta;

a national competition of innova-tions and self-sufficient IT-projects and solutions based on the Open Data Chal-lenge in order to provide a possibility for developers, entrepreneurs, designers and public activists to use open data for devel-oping services and provides that will facili-tate solving problems of the Ukrainian society.

The winners of the competitions were the Open Coal Market project - an online auction for selling coal, the Court on a Palm - an analytical

\footnotetext{
${ }^{8} 6$. Transformation of international economic relations: modern challenges, risks, opportunities and prospects: collective monograph. edited by M. Bezpartochnyi, in 3 Vol. ISMA University. Riga: «Landmark» SIA, 2017. Vol. 3. P. 115.
} 
instrument for searching, studying and visualizing court decisions, and Штрафи.UA [Fines.UA] - a mobile tracking technology that offers a possibility to determine the quality of driving using telemetric features of a smartphone. The winners received finan-cial prizes totaling 600, 500 and 400 thou-sand hryvnias.

Based on the results of the Open Data Leader contest, the most progressive leaders were determined in the open data sphere among state institutions, civil soci-ety organizations and businesses in six categories:

Open Data Business Award (for the most efficient use of open data for trans-forming business) - Open Data Bot service - monitoring registration data of Ukrainian companies and the court regis-ter for protection from illegal takeovers and control of contract partners;

Open Data Government Award (for the highest standards of publication of open data by central management bodies) - Ministry of Justice;

Open Data City Award (for the high-est standards of publication of open data by local management bodies) - Lviv City Council. The Breakthrough of the Year - Dnipro City Council;

Open Data Social Impact Award(for the largest social impact of the use of open data) - the Better Regulation Deliv-ery Office, BRDO - a non-governmental structure crated for accelerating the reform process in Ukraine;

Open Data Leader Award (for the best personal merits in open data devel-opment) - Andrii Hazin, a journalist and analyst of Texty.org.ua;

Open Data Media Award (for the best use of open data in journalism) Kantselarska Sotnia- an organization dealing with decryption and digitalization of declarations of officials, council members, law enforcement officers, and other civil servants.

Implementation Challenges and Risks:

- Absence of a uniform consolidated resource in Ukraine that would contain information about all state registers (135 state registers in more than 40 state authorities);

- Imperfect legislation regulating general principles of creation and mainte-nance of state registers, which results in a large number of heterogeneous state resources not designed for electronic interaction;

- Difficulty with developing a one-stop-shop system for e-services. Indi-vidual services are developed through individual departmental systems and local self-government bodies 
- Absence of methodology and procedure for evaluation of provision of administrative services that makes it impossible to assess objectively the quali-ty of provision of administrative services in the CPAS and eservices.

\section{Novelties of Public Administration in Ukraine}

20 Deliverables by 2020, a joint Eastern Partnership working document, says that the member-states should improve the quality of governance by strengthening institutions and implementing proper governance practices. When Ukraine adopted the Public Administration Reform Strategy in 2016, it declared commitment to the Principles of Public Administration developed by SIGMA (Support for Improvement in Governance and Management). The EU provides sectoral budget support to Ukraine for implementing a comprehensive public administration reform.

SIGMA's Principles of Public Administration cover six core areas: the strategic framework for public administration reform; policy development and coordination; public service and human resource management; accountability; service delivery, and public financial management.In a nutshell, this is the EU's model for relatively good governance. Since 2015, SIGMA has done a comprehensive assessment of the extent to which public administration complies with these Principles in seven candidates and potential candidates for joining the EU, as well as in Moldova, Georgia and Ukraine. The results of this assessment define the starting point for work towards the goal of improving public administration and for the roadmap of reforms ${ }^{9}$.

The assessment of Ukraine was conducted upon request from its government using the methodology applied to the candidates for EU membership. The criteria are harsher than those used for the European Neighborhood Policy (ENP) countries.

The response of different government institutions and expert groups to the findings varied. SIGMA found that "overall, Ukraine has already made considerable progress in reforming some areas of its public administration". In September 2018, the EU decided to issue another tranche of sectoral budget support to it. Ukraine received 3 or more points out of 5 in half of all the criteria. At the same time, little has been done on

\footnotetext{
${ }^{9}$ Public administration reform in Ukraine: A review of accomplishments. Natalia Kupriy, Central Ukrainian Foundation for Development Support (Kyiv, Ukraine). [Elektronnyy resurs]. http://prismua.org/en/pdf/2019. 02-8.
} 
nearly $20 \%$ of the criteria. According to the EU experts, Ukraine's indicators are overall better than those of Western Balkan candidates and potential candidates for EU membership that have long been in the process of reforms, and still better than of those countries in the "civil service" segment.

Ukraine's Cabinet of Ministers took into account the findings of the assessment and used them as the basis for updating the Public Administration Reform Strategy in December 2018.

What specific results of the reform effort are visible by now? First of all, Ukraine's ranking in a number of indices points to some progress in this key reform. It went 34 points up to position 65 in Transparency of Government Policymaking in the 2018 Global Competitiveness Index by the World Economic Forum. Also, it improved its position by 23 points to rank 31st in the Open Data Index.

Ministries are undergoing restructuring, with the respective procedures for analysis and government policymaking integrated into their work. Ten pilot ministries and the Secretariat of the Cabinet of Ministers have introduced new apparatus structures.

Among other things, general policy directorates and directorates for strategic planning and European integration were established. This allows the ministries to gradually shed excessive functions of public property administration and administrative service provision, and of the routine "administration of the national economy", a standard function of the oldschool administration. Starting from 2018, impact outlook will be a mandatory element of decision making in the government. This means defining target groups and the impact these decisions will have on them in the short and long term .

1,300 posts of reform specialists were introduced in the government bodies, with almost half of them already filled through open, transparent competitions with nearly 19,000 applicants. A special procedure for the selection of reformers allowed the government to hire people experienced in civil service and external specialists with respective competency and experience in business and non-government sector. The new general directorates are staffed with graduates of some top international European and American universities, and specialists with experience in think tanks and investment companies, well-known NGOs and projects, including 
Tabletochki foundation, National Anti-Corruption Platform, FactcheckUkraine project and more ${ }^{10}$.

When the new law on civil service came into effect in 2016, it essentially made a huge step towards the creation of professional, stable and politically neutral civil service. The institute of state secretaries was introduced in the ministries. Currently, new people are hired and promoted in civil service through competition exclusively. Replacements in the top echelons of civil service are based on a competition held by the designated Commission for the Top Segment of Civil Service. 60\% of the Commission members represent civil society, including trade unions and employers' associations. What is more, since 2018 there has been a stricter requirement for contenders for the top segment of civil service to have the A2+ command of a foreign language, English or French, proven by the respective tests.

The new philosophy of civil service requires new approaches to personnel management. For this purpose, HRM departments have been introduced in all government bodies, replacing the current "staff management units" whose only function was to keep records on human resources. In 2019, Ukraine plans to launch the HRMIS staff management information system with the functions of hiring staff for civil service and keeping record of it, assessing professional activity, organizing professional learning and tracking salary progress.

2018 saw the first full cycle of assessing civil servants' work based on Key Performance Indicators (KPIs). The results serve as a basis for individual programs of personal development for civil servants, as they focus on identifying the competencies to be developed further and the education programs to be used for that purpose on a yearly basis.

The reform of civil servant salary system was launched. Starting from 2019 , a solid system is in place whereby $70 \%$ of the salary is a permanent component tied to subsistence minimum and $30 \%$ is the variable bonus component. This approach allows employers to minimize the subjective factor and bias in remunerating for civil service. According to The Reform of Remuneration for Civil Servants, a study by the independent Center for Economic Strategy, Ukraine has competitive wages for civil servants on the local level, while the wages for civil servants in central authorities are still below the ones in the private sector.

\footnotetext{
10 Anticorruption in Ukraine: Unbiased Overview. [Elektronnyy resurs]. https://voxukraine.org/en/anticorruption-in-ukraine-en.
} 
The system of administrative services is a special priority. It is an essential component of proper public administration that defines how taxpayers experience its quality. At the end of 2018, the Cabinet of Ministers approved the Law of Ukraine On Administrative Procedure and submitted it to the Parliament. This framework law defines an essentially new policy for administrative service provision.

The Single Portal for Administrative Services was launched allowing citizens to receive many administrative services electronically, which minimizes corruption and speeds up the service. International technical assistance has helped Ukraine expand the network of one-stop-shop or front-office Administrative Service Centers (ASCs). By 2018, 775 ASCs were in operation and have provided 11 million services so far. Individuals and legal entities get an average of over 40,000 services through all ASCs daily ${ }^{11}$.

Based on the government decision, the Single State Open Data Portal works at www.data.gov.ua. It has published over 27,500 data sets and registered over 2,000 data set administrators.

All these accomplishments do not overshadow challenges in the public administration reform. Moreover, criticism will get more prominent as Ukraine walks further into the political turbulence over the 2019 presidential and parliamentary elections. All transformations, especially in public service, are not yet stable enough, which remains the key challenge. If the government changes after the parliamentary election, they will have to stand the test of the change. Late 2019 will show the extent to which public administration is resilient to political influence, especially on staffing the top offices, managing the system of salaries, and continuing reformist positions in ministries. Another worrying factor is financial unsustainability of the reform implementation.

Noteworthy is some perfectly obvious internal resistance to reforms. A good illustration to this will be the intensified efforts of the newlyelected Audit Chamber to undermine many reformist programs and projects through audits that often provide controversial findings.

Undoubtedly, the system of strategic planning, administrative procedure and government policymaking procedure are still far from being fully operational.

The next steps on the crucial public administration reform should be more decisive. Hopefully, Ukraine will manage to navigate through the

\footnotetext{
11 Anticorruption in Ukraine: Unbiased Overview. [Elektronnyy resurs]. https://voxukraine.org/en/anticorruption-in-ukraine-en.
} 
election turbulence and deliver the expected results in 2020. The reform can not last forever. If protracted too long, it risks drowning itself without delivering the expected result.

\section{CONCLUSIONS}

Account current scientific approaches to economic zoning the most optimal will be the allocation of six integrated social and economic regions: Central (Vinnytsya, Zhytomyr, Kyiv, Khmelnytsky, Cherkasy, Chernihiv regions), Eastern (Donetsk, Luhansk regions), Western (Volyn, Transcarpathian, Ivano-Frankivsk, Lviv, Rivne, Ternopil, Chernivtsi region), EastCentral (Dnipropetrovs'k, Zaporizhia regions), Southern (Mykolaiv, Odesa, Kherson regions and Autonomous Republic of Crimea), Northeastern (Poltava, Sumy, Kharkiv region), with corresponding centers Kyiv, Donetsk, Lviv, Dnipropetrovsk, Odesa, Kharkiv. For the development of proposals for the improving of legal regulation of regional development and local self-government reformation in Ukraine the Ukrainian-Polish advisory group was created by the signing of the Memorandum of Cooperation about the support of local government reform in Ukraine on December 17, 2014 in Warsaw.

The Ukrainian-Polish advisory group plans to assess the implementation of existing decisions on financial decentralization; prepare the proposals regarding amendments to the Budget and Tax Code of Ukraine in terms of financial decentralization; strengthen the financial basis of local self-government considering the budgetary performance; work out the mechanisms to ensure public and state control of public finances.

The basic plan to reduce the risks of providing administrative services is: continued work on the project for implementation of the basic principles and rules of administrative procedure in accordance with the European standards; implementation of the electronic interaction system TREMBITA, and connection of minimum 20 basicregisters to einteraction; introduction of an integrated system of electronic identification with the help of all e-ID means - digital signa-ture, BankID, MobileID, ID-card in one servise; introduction of more than 20 new priority electronic administrative services, namely permits for transportation; vehicle registration, childbirth registration, etc; increase of the number of recipi-ents of electronic administrative services online to $30 \%$; increase of the list of CEB services that are provided through the centers for provision of administrative services to 136; ensuring 
implementation of the plan of accessibility of administrative services through the increase of a number of CPAS, geographic coverage and better functioning; introduction of re-engineering for 15 most popular services. Development and adoption of the procedure for provi-sion of administrative services built around citizens' needs (citizen-centric policy); introduction of the principle of one entry of data, definition of terminology for basic notions of the system of elec-tronic interaction, its objects and subjects, modernization of the National Register of Electronic Information Resources; development of the uniform state open data webportal that will make it possible to process data set formats in an automatic mode that are uploaded to the portal for avoiding uploading erroneous formats.

\section{SUMMARY}

The complexity of the tasks of public administration is that the changes in the Ukrainian government structures observed in recent decades have failed to overcome the cumbersome, non-transparent administrative-command system, to create an effective public administration. Unfortunately, the research on public administration pays little attention to anti-crisis technologies; not sufficiently developed and justified in both global and domestic practice are the mechanisms for implementing the objectives of public management in crisis conditions, methods and procedures of their bodies' activities. So, today's crisis of Ukrainian politics is above all a crisis of confidence. People have lost confidence in political institutions, in the virtue of leading politicians and parties, institutional capacity of the government and its leaders to implement reforms in democratic direction that was won and clearly proclaimed by the Revolution of dignity. In turn, politicians do not trust either each other or the society and no longer rely on the support from citizens. This makes governmental institutions unable to purposefully lead the country through reforms. Therefore, the definition of strategic and perspective directions of public administration reform according to the best European and world standards provides a comprehensive approach in the coordinate system of modern Ukraine and demands socially equitable governance that would ensure harmonization of public interests and the interests of society the most effectively. This is possible thanks to the improvement of the system of public administration and balancing the interests of all members of society. The material used in the study has only the analysis of information resources. 


\section{REFERENCES}

1. The Constitution of Ukraine: Official text - Kyiv : Palyvoda A. V. 2016. 64 p.

2. Derzhavna sluzhba statystyky Ukrayiny [Elektron. resurs]. http://www.ukrstat.gov.ua/.

3. Zakon Ukrayiny «Pro dobrovil'ne ob'yednannya terytorial'nykh hromad» [Elektronnyy resurs]. http://zakon4.rada.gov.ua

4. Proekt metodyky formuvannya spromozhnykh terytorial'nykh hromad [Elektronnyy resurs]. http://www.minregion.gov.ua.

5. Kolosov V. Territorial units in Russia,Ukraine, Belarus and Moldova and NUTS classification. V. Kolosov. [Elektronnyy resurs]. http://www.ums-riate.fr/Webriate/wp-content/uploads/2015/03/M4D.pdf.

6. Transformation of international economic relations: modern challenges, risks, opportunities and prospects: collective monograph. edited by M. Bezpartochnyi, in 3 Vol. ISMA University. Riga: «Landmark» SIA, 2017. Vol. 3. 197 p.

7. Report On The Investigation Into Russian Interference In The 2016 Presidential Election. Volume I of II. Special Counsel Robert S. Mueller, III. Submitted Pursuant to 28 C.F.R. § 600.8(c). Washington, D.C. March 2019. [Elektronnyy resurs]. https://www.nytimes.com/interactive/ 2019/04/18/us/ politics/mueller-report-document.html.

8. Public administration reform in Ukraine: A review of accomplishments. Natalia Kupriy, Central Ukrainian Foundation for Development Support (Kyiv, Ukraine). [Elektronnyy resurs]. http://prismua.org/en/pdf/2019-02-8.

9. Anticorruption in Ukraine: Unbiased Overview. [Elektronnyy resurs]. https://voxukraine.org/en/anticorruption-in-ukraine-en.

\section{Information about the author: Bortnyak K. V.}

Candidate of Law Sciences, Assistant Professor, Assistant Professor at the Department of Constitutional and International Law of the Educational and Humanitarian Institute of the V. I. Vernadsky Taurida National University

33, Ivan Kudria str., Kyiv, Ukraine 